\title{
Genotoxicity and cytotoxicity assay of water sampled from natural reservoirs with contrast level of radioactive and chemical contamination
}

\author{
T. Evseeva ${ }^{1}$, S. Geras'kin ${ }^{2}$, I. Shuktomova ${ }^{1}$ and A. Taskaev ${ }^{1}$ \\ ${ }^{1}$ Institute of Biology, Komi Scientific Center, Ural Division RAS, Kommunisticheskaya 28, \\ 167982 Syktyvkar, Russia \\ ${ }^{2}$ Russian Institute of Agricultural Radiology and Agroecology, 249020 Obninsk, Russia
}

\begin{abstract}
Comparative analysis of water from natural reservoirs located near a place of the underground nuclear explosion with rock outburst (Perm region) and the radium production industry storage cell (Komi Republic) with contrast levels of radioactive and chemical contamination was performed for the first time using bioindication and chemical analysis. Bioindication was carried out with anaphase-telophase chromosome aberration assay on A. schoenoprasum L. meristematic root tip cells. Even at very low levels of specific activity, both natural $\left({ }^{238} \mathrm{U},{ }^{232} \mathrm{Th},{ }^{226} \mathrm{Ra},{ }^{210} \mathrm{Po},{ }^{210} \mathrm{~Pb}\right)$ and artificial $\left({ }^{90} \mathrm{Sr},{ }^{137} \mathrm{Cs},{ }^{230,240} \mathrm{Pu}\right)$ radionuclides contribute significantly (59-91\%) to an induction of genotoxic and toxic effects. The chemical factors strengthened or weakened the cytotoxicity effects and may modify a formation of certain type of chromosome disturbances. Our results clearly indicate that combined exposure to metal ions and radionuclides at levels officially adopted as permissible for humans may act synergistically and result in significant damage to different biota species.
\end{abstract}

\section{INTRODUCTION}

Present-day radiation environment in many regions of the world advances a question about not only on-line monitoring of the radioactive contamination, but also a reassessment of the ionizing radiation exposure consequences for biota in various radioecological situations taking into account a new scientific knowledge. Most attention is paid to study of severe nuclear accidents consequences, monitoring of nuclear weapon test sites and zones in the vicinity of nuclear facilities. Nevertheless, we cannot fail to attend local radioactively contaminated sites that were formed as a result of human industrial activity. Those sites, that have been isolated from the man-caused influence for a long time, are unique testing areas both for studying regularities of a radionuclides redistribution in the environment in the course of time and assessing consequences of radiation exposure to biota in different ecological conditions. Such information is an indispensable cornerstone for developing the principles of radioprotection of living nature. In this paper, we describe the results of an integrated assessment of water bodies located: 1) in the site of the underground nuclear explosion with soil excavation in the north of the Perm region and 2) on the radium production industry storage cell territory (a settlement of Vodniy, the Republic of Komi) performed by both bioindication and chemical-analytical methods. 


\section{MATERIALS AND METHODS}

\subsection{Study sites}

Water samples were taken (Fig. 1) in 2001 from the surface (№. 1) of a lake formed in the nuclear explosion epicenter, from $5 \mathrm{~m}$ (№. 2) and $10 \mathrm{~m}$ depth (№. 3). Sample №. 4 was taken from a well $50 \mathrm{~m}$ far from the lake, №. 5 - from a microreservoir close to the lake, №. 6 - from a bog 200-300 m far from the lake, and №. 7 - downstream the Berezovka river on a large distance $(3 \mathrm{~km})$ from the explosion site.

At the settlement of Vodniy (Fig. 2) water samples were taken in 2002 from springheads (referred to as № 1 and № 2) and mouths (№ 3 and № 4) of Brook I and Brook II. These brooks run across the storage cell territory and flow into the Uchta River. Brook II drains uranium wastes brought here in 1947, whereas Brook I does not. Sample № 5 was taken from a little reservoir, formed by Brook I near the foot of the Uchta first terrace. Sample № 6 was taken from the Uchta River $300 \mathrm{~m}$ downstream from the storage cell. Sample № 7 was taken from a springhead in the central part of the Chyut riverbank. This area is located far away from the storage cell and is therefore not polluted by the uranium wastes. Several decades ago, the underwater contained high radium, thorium, heavy and alkaline metal concentrations as well as free and bound carbonic acid [1]. The water sample № 8 was taken from the Uchta River outside of a zone of anthropogenic and technogenic influence.

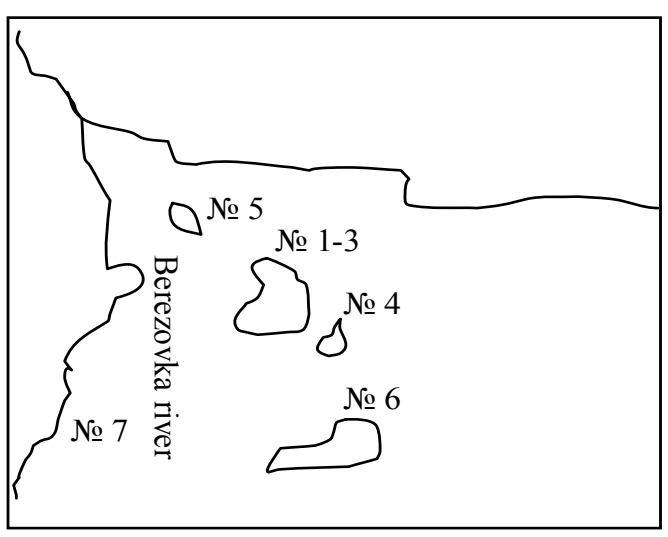

Figure 1. Map of the underground nuclear explosion site in the north of the Perm region, Russia.

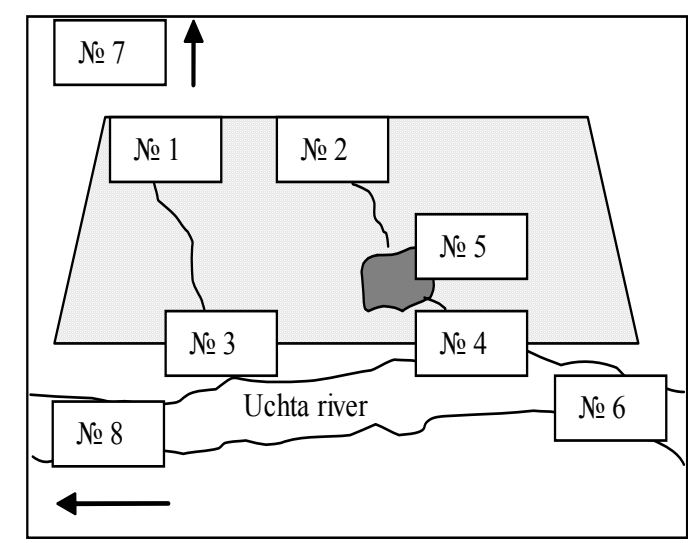

Figure 2. Map of the storage cell territory (shaded), the settlement of Vodniy, the Republic of Komi, Russia.

\subsection{Allium-test}

The anaphase-telophase chromosome aberration assay on Allium schoenoprasum L. $(2 \mathrm{n}=16)$ root tips was used to test samples genotoxicity. The sample cytotoxicity was estimated based on a root proliferation that was therefore quantified for all the samples as the mitotic index. The developing roots were maintained at $22 \pm 2^{\circ} \mathrm{C}$. When the roots began to grow (up to $0.2 \mathrm{~cm}$ length), the bulbs were plunged into the water samples to be studied. Control samples remained in distilled water (for more details, see [2]). Distilled water was chosen for the bulb germination on the basis of our previous experiments where the reaction of Allium cepa root tip cells to environmental pollutants were showed to be regardless of whether these pollutants were supplied in a Knop medium or distilled water. It is in line with the results obtained in $[3,4]$. 


\subsection{Determination of heavy metals (HMs) and radionuclides (RNs) concentrations}

Water samples chemical analysis was performed in concomitance with the biological assay. $\mathrm{K}$ and $\mathrm{Na}$ concentrations in water samples were determined by flame photometry method according to the attested and confirmed method registered in the RD 52.24.391-95 State Register. Atomic absorption method was used for measuring $\mathrm{Ca}$ and $\mathrm{Mg}$ content (RD 52.04.186-89) and $\mathrm{Cu}, \mathrm{Pb}, \mathrm{Cd}, \mathrm{Zn}, \mathrm{Mn}, \mathrm{Ni}$ (RD 52.24.377-95). Radiochemical analysis for assessing RNs contents in water samples was performed in the Radiochemical laboratory of the Institute of Biology of Komi Scientific Center accredited within the Accrediting System for analytical laboratories in Russia (for more details, see [2]). The results were subjected to statistical analysis by means of generally accepted methods [5].

\section{THE WATER BODIES CONTAMINATION ASSESSMENT AT THE UNDERGROUND NUCLEAR EXPLOSION SITE}

The results of the cytogenetic analysis are shown in Fig. 3. Statistical analysis revealed apparent differences in the aberrant cells frequency from the control levels when testing water samples №. 1-3 from the lake formed in the explosion epicenter.

Mitotic index of Allium schoenoprasum root cells cultivated in the lake water samples is found significantly different from control by t-test (Fig. 3). But, it is not related to an increased cell proliferative activity. To the contrary, an increased frequency of vagrant chromosomes observed in

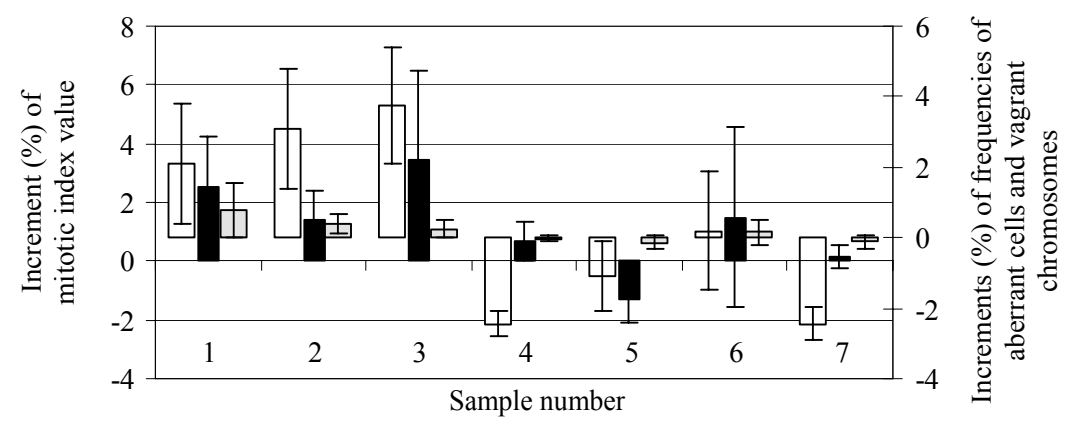

Figure 3. Mitotic index in Allium schoenoprasum root tips cells and cytogenetic disturbances induced by pollutants contained in the water sampled from the underground nuclear explosion site

- mitotic index;

aberrant cells frequency;

$\square$ - vagrant chromosomes frequency

Samples 1-7 are denoted in Fig. 1. Each experimental point represents the mean and standard deviation.

samples № 1-3 might be related to weak anti-mitotic effect [3, 6]. Water samples taken from the well (№. 4) and the river (№. 7) induced mutagenic effect significantly lower than in control (Fig. 3). Genotoxicity of samples from a micro-reservoir close to the lake (№. 5) and from the bog (№. 6) is below control as well. Nevertheless, sample №. 5 has a significantly increased cytotoxicity. As a whole, a local biologically relevant contamination of surface water was revealed by means of Allium-test in the radionuclide anomaly (samples 1-3), formed as a result of the underground nuclear test in the north of the Perm region (Russia).

It can be seen in Table 1 that the water samples №. 1-3 from the lake formed in the explosion epicenter substantially differs from the others because of increased total contents of both HMs and RNs. Nevertheless, specific activities of main dose-forming radionuclides in all examined reservoirs are below the intervention levels officially adopted in Russia for drinking water [7]. On the other hand, Na concentration in samples №. 1-3 exceeds maximum permissible levels for both fisheries and drinking water.

The main pollutant contribution to cytotoxicity and genotoxicity of a water sample was identified 
based on a stepwise method of regression analysis. Its application indicates that sample genotoxicity is in positive correlation with the contentsof ${ }^{90} \mathrm{Sr},{ }^{239,240} \mathrm{Pu}$, but in negative correlation with $\mathrm{Mg}$ content:

$$
\mathrm{AC}=-2.92+2.58\left[{ }^{90} \mathrm{Sr}\right]+299.23\left[{ }^{239,240} \mathrm{Pu}\right]-0.74[\mathrm{Mg}] \text {, }
$$

where $\mathrm{AC}$ - aberrant cell frequency (\%); in square brackets - concentration of the radionuclides $\left(\mathrm{Bq} / \mathrm{dm}^{3}\right)$ and metals $\left(\mathrm{mg} / \mathrm{dm}^{3}\right)$.

Indices of approximation qualities: $\mathrm{R}^{2}=0.79 ; \mathrm{F}=33.39 ; \mathrm{p}_{\mathrm{f}}<0.001$.

The average number of vagrant chromosomes per 100 anaphase-telophase, which appearance could be referred to low anti-mitotic effect, increased in parallel to $\mathrm{Na}$ and ${ }^{137} \mathrm{Cs}$ levels, and inversely proportional to $\mathrm{Zn}$ concentration:

$$
\mathrm{VC}=0.77+5.46 \cdot 10^{-3}[\mathrm{Na}]+57.07[\mathrm{Cs}]-302.32[\mathrm{Zn}],
$$

where $\mathrm{VC}$ - vagrant chromosomes frequency (\%). Indices of approximation qualities: $\mathrm{R}^{2}=0.77$; $\mathrm{F}=30.66 ; \mathrm{p}_{\mathrm{f}}<0.001$.

Table 1. Concentration of artificial radionuclides $\left(\mathrm{Bq} / \mathrm{dm}^{3}\right)$, alkaline and heavy metals $\left(\mathrm{mg} / \mathrm{dm}^{3}\right)$ in water samples from the underground nuclear explosion site.

\begin{tabular}{|c|c|c|c|c|c|c|c|c|c|}
\hline \multirow{2}{*}{ Ion } & \multicolumn{7}{|c|}{ Sample number } \\
\cline { 2 - 9 } & 1 & 2 & 3 & 4 & 5 & 6 & 7 & \multirow{2}{*}{ C } \\
\cline { 2 - 9 } & \multicolumn{7}{|c|}{ Cation concentration } & \\
\hline${ }^{90} \mathrm{Sr}$ & 3.31 & 3.69 & 3.20 & 0.06 & 0.51 & 0.04 & 0.13 & 5.00 \\
\hline${ }^{137} \mathrm{Cs}$ & 0.010 & 0.002 & 0.002 & 0.010 & 0.010 & 0.020 & 0.020 & 11.00 \\
\hline${ }^{239,240} \mathrm{Pu}$ & 0.010 & 0.010 & 0.020 & 0.010 & 0.006 & 0.010 & 0.003 & 0.56 \\
\hline$\Sigma_{\mathrm{AHM}}$ & 362.45 & 353.12 & 374.67 & 32.40 & 6.14 & 9.77 & 12.58 & - \\
\hline$\Sigma_{\mathrm{RN}}$ & 3.330 & 3.702 & 3.222 & 0.080 & 0.526 & 0.070 & 0.153 & - \\
\hline
\end{tabular}

$\mathrm{C}$ - intervention level officially adopted in Russia for drinking water, $\mathrm{Bq} / \mathrm{dm}^{3}$, [7].

$\Sigma_{\mathrm{AHM}}-$ alkaline and heavy metals total concentration in water samples;

$\Sigma_{\mathrm{RN}}$ - radionuclides total concentration in water samples.

\section{THE WATER BODIES CONTAMINATION ASSESSMENT AT THE RADIUM PRODUCTION INDUSTRY STORAGE CELL TERRITORY}

All water samples (except № 8) caused a significant increase of the aberrant cell frequency as compared to control (Fig. 4). Statistically significant toxic effect was only identified in samples № 1 and № 2 (from brook springheads). The water sampled from the Uchta River (№ 6) caused a significant increase of the mitotic index in Allium root tips cells as compared to the control. However, increased frequency of vagrant chromosomes observed in those samples is the indicator of weak anti-mitotic effect.

The results of the chemical analysis (Table 2) demonstrated that ${ }^{262} \mathrm{Ra},{ }^{228} \mathrm{U},{ }^{232} \mathrm{Th},{ }^{210} \mathrm{~Pb}$ and ${ }^{210} \mathrm{Po}$ concentrations in samples № 1-5 from the storage cell territory were higher than in samples № 6, 7 and 8 taken outside the territory. Nevertheless, the overall HNRs concentrations in all samples were found not to exceed the radioactivity concentration guides. $\mathrm{Zn}$ and $\mathrm{Mn}$ levels in all samples analysed as well as $\mathrm{Ca}$ from Brook II exceeded the maximum permissible concentrations for natural reservoirs [2].

The regression analysis indicates that sample genotoxicity depends mainly on ${ }^{232} \mathrm{Th},{ }^{238} \mathrm{U}$ and ${ }^{210}$ Po concentrations.

$$
\mathrm{AC}=0.40+7.48\left[{ }^{232} \mathrm{Th}\right]+0.19\left[\left[^{238} \mathrm{U}\right]-1.86\left[{ }^{210} \mathrm{Po}\right]\right.
$$

Indices of approximation qualities: $\mathrm{R}^{2}=0.76 ; \mathrm{F}=39.28 ; \mathrm{p}_{\mathrm{f}}<0.001$ 
Table 2. Concentrations of heavy natural radionuclides (HNR, $10^{-2} \mathrm{~Bq} / \mathrm{dm}^{3}$ ), and heavy and alkaline metals $\left(\mathrm{HM}, \mathrm{mg} / \mathrm{dm}^{3}\right)$ in water samples.

\begin{tabular}{|c|c|c|c|c|c|c|c|c|c|}
\hline \multirow{3}{*}{ Ion } & \multicolumn{8}{|c|}{ Sample number } & \multirow{3}{*}{$\mathrm{C}$} \\
\hline & 1 & 2 & 3 & 4 & 5 & 6 & 7 & 8 & \\
\hline & \multicolumn{8}{|c|}{ Cation concentration } & \\
\hline${ }^{238} \mathrm{U}$ & 4.06 & 20.90 & 2.71 & 10.80 & 0.92 & 1.06 & 0.14 & 0.83 & 310 \\
\hline${ }^{232} \mathrm{Th}$ & 0.39 & 0.25 & 0.51 & 0.25 & 0.47 & 0.52 & 0.37 & 0.12 & 60 \\
\hline${ }^{226} \mathrm{Ra}$ & 3.26 & 48.80 & 1.90 & 11.20 & 20.40 & 3.48 & 1.55 & 3.79 & 50 \\
\hline${ }^{210} \mathrm{Po}$ & 0.04 & 0.36 & 0.64 & 0.09 & 0.11 & 0.05 & 1.10 & 0.61 & 12 \\
\hline${ }^{210} \mathrm{~Pb}$ & 1.41 & 0.80 & 2.45 & 0.70 & 4.59 & 1.05 & 0.80 & 0.52 & 20 \\
\hline$\Sigma_{\mathrm{RN}}$ & 9.16 & 71.11 & 8.21 & 23.04 & 26.49 & 6.16 & 3.96 & 5.87 & - \\
\hline$\Sigma_{\mathrm{AHM}}$ & 127.56 & 267.40 & 133.12 & 243.00 & 216.35 & 74.85 & 144.68 & 86.37 & - \\
\hline
\end{tabular}

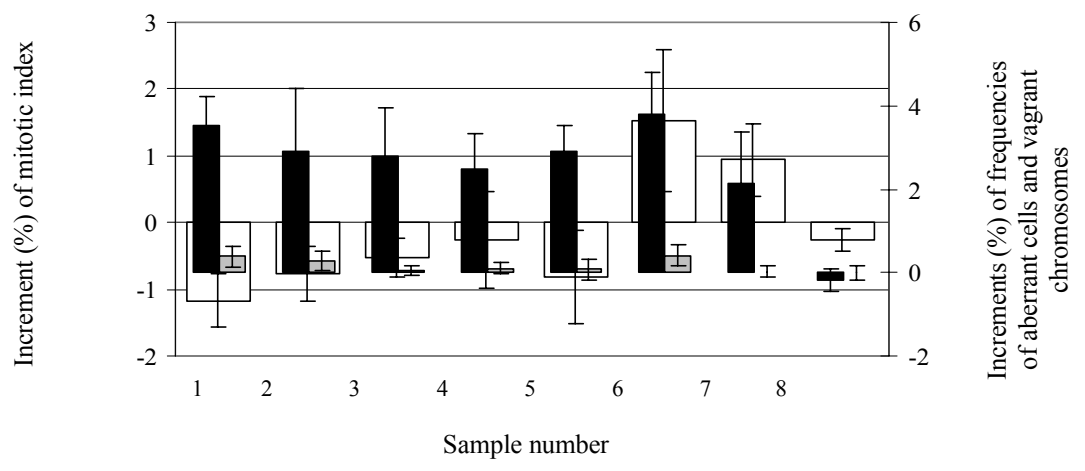

Figure 4. Mitotic index in Allium schoenoprasum root tips cells and cytogenetic disturbances induced by pollutant: contained in the water sampled from the storage cell territory, based on the anaphase-telophase

- mitotic index

- aberrant cells frequency;

Samples 1-8 are denoted in Fig. 2. Each experimental point represents the mean and standard deviation.

The mitotic index increased with $\mathrm{Zn}$ ion levels, and inversely proportional to ${ }^{238} \mathrm{U}$ concentrations:

$$
\mathrm{MI}=-1.43+53.01[\mathrm{Zn}]-0.04\left[\left[^{238} \mathrm{U}\right]\right. \text {, }
$$

where MI - mitotic index (\%). Indices of approximation qualities: $\mathrm{R}^{2}=0.88 ; \mathrm{F}=136.43 ; \mathrm{p}_{\mathrm{f}}<0.001$.

\section{CONCLUSION}

The radionuclide anomaly in the Perm region was formed 31 years ago, and in Vodniy - 56 years ago. Since that the exposure dose rate of external $\gamma$-radiation has significantly decreased, and specific activities of main dose-forming radionuclides in all examined reservoirs are below the intervention levels officially adopted in Russia for drinking water. Only the concentrations of some heavy metals exceeded the maximum permissible concentrations for natural reservoirs. The results of Allium-test appeared positive for most water samples. It is important that the levels of genotoxicity and cytotoxicity of water samples were to a great extent determined not by separate metals concentrations but by combined action of HMs and RNs, although some metals concentrations exceeded the maximum permissible concentrations for natural reservoirs. It is advisable to note that both the natural and artificial RNs play a vital role in the cytogenetic disturbances induction, even when their specific activities in water bodies are extremely low. From a practical point of view, special attention must be 
paid to the fact that RNs induced a substantial biological effect even at low specific activities in natural water sources. The chemical factors strengthened or weakened the cytotoxicity effects and may modify a formation of certain type of chromosome disturbances.

Our results prove that an adequate pollutant screening cannot rely only on pollutant concentrations. A concentration determination provides a detailed characterization of the acting agents, but only indirectly points out at the potential biological consequences. Besides, authorities in charge of controlling the levels of industrial load have dealt with limited lists of toxicants. Biological monitoring, in turn, provides an integrative estimation of toxicity and genotoxicity of environmental pollutants. A combination of biological and pollutant chemical control methods allow identifying the major sources of risk, which require a continuous monitoring. Our previous [2] and described here data suggest that combined exposure of metal ions and radionuclides on the various biota species with the dose below permissible exposure limits for human may cause substantial biological effects, in part due to synergic response.

\section{References}

[1] Bogoiavlenski L.N., Doklady of Academy of Scienses USSR 14/15 (1928) 156. (in Russian).

[2] Evseeva T.I., Geras'kin S.A. and Shuktomova I.I., J. Environ. Radioact. 68 (2003) 235-248.

[3] Wierzbicka M., Protoplasma 207 (1999) 186-194.

[4] Marcano L., Carruyo I., Campo A. and Del Montiel X., Environ. Res. 94 (2004) 221-226.

[5] Sokal R. and Rohlf F., Biometry. (W.H. Freeman, New York, 1995) pp. 850.

[6] Fiskesjo G., Mutat. Res. 197 (1988) 243-260.

[7] Radiation safety norms: hygienic standards (Sanitary-epidemiologic normalization, hygienic certification and inspection center of Russia Department of Health. Moscow, 1999) pp. 116. (in Russian). 